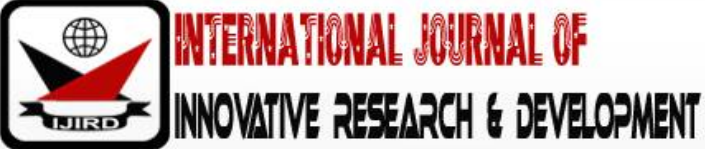

ISSN 2278 - 0211 (Online)

\section{Junior High School Counselors' Perceptions toward Multicultural Competence}

\begin{tabular}{c} 
Heru Mugiarso \\
Associate Professor, Universitas Negeri Semarang, Indonesia \\
Mungin Eddy Wibowo \\
Professor, Universitas Negeri Semarang, Indonesia \\
Sugiyo \\
Professor, Universitas Negeri Semarang, Indonesia \\
Edy Purwanto \\
Associate Professor, Universitas Negeri Semarang, Indonesia \\
\hline
\end{tabular}

\begin{abstract}
:
Multicultural competence is an important and required competence by counselors whom work in multicultural society background. The reality shows that this competence has been developed because there is no interest of multicultural counseling reviews. This research aims to obtain counselor perspective at Junior High School level in Semarang about multicultural competences. By using questionnaire given to 115 counselors/Guidance and Counseling teachers and descriptive statistics method analysis, it was obtained that most of counselors had positive and meaningful perceptions toward multicultural competences which they assumed important and useful in carrying out their tasks. However, they argued that there was a need of self-development through training. This research implicates the needs of training model to develop Indonesian culture based multicultural competences.
\end{abstract}

Keywords: School counselor perception, multicultural competences

\section{Introduction}

For the last several decades, multicultural competence becomes an important issue for counselors whom work in multicultural society background. Multicultural competence is a competence covering required awareness, knowledge, and skills to connect effectively to various ethnics and cultures from various groups (Pope and Reynold, 1997)6. Urgent reason toward the competence requirement appears due to development of interest and attention of counseling science toward multicultural matter as inevitability of multicultural society and real-life order which goes global and gets more complex (Supriadi, 2008) ${ }^{10}$. That fact is slightly different with several previous decades' tendencies when counseling still prioritized psychological approach and ignores cultural approach. It is not only that one. Research takes a closer look that multicultural competence is strongly correlated to job efficiency to assist clients (Sue and Sue, 2003) ${ }^{9}$.

Orientation changes and absolute approach of psychological discipline on counseling, by considering cultural approach, occurred when counseling experts realized that counselees were not just psychological creatures but they are anthropological creatures. Therefore, counseling does not only emphasize on psychological natures of homogeneous individuals (ethics) but also emphasizes on multicultural natures (emics) (Supriadi, 1998; Pedersen, Dragun, loner and Trimble, 1996). ${ }^{5}$

From cultural perspective, counseling is a cultural assimilation between a counselor and a client (Supriadi, 1998) ${ }^{10}$. Therefore, by involving different cultured counselor and client, then counseling process is susceptible to cultural biases on counselor party which could cause counseling does not run effectively (Pedersen et al,1996). ${ }^{5}$

To avoid failures in conducting counseling, counselor is required to be aware of cultures, to be ready to dispatch himself from any cultural biases and to have responsive skills culturally (Loekmono, 2009) ${ }^{3}$. Yogi (at Hladik et. Al, 2016$)^{2}$ asserted that a responsive counselor culturally should apply knowledge, awareness, and skill into his multiculture to face various clients' problems which come from different cultural environments.

Increasing Indonesia citizen diversification creates challenges for School Counselors. Diversification of our society which consists of various ethnics, races, and religions are susceptible to conflict as seen recently. Various emerging occurrence in the mist of pluralism society, such as dimensional - multicultural conflict is assumed to have impacts on school learners. Increasing harassment on behalf of social statuses at school, hostility on behalf of hatred to students whom have different religion are some of the examples. Therefore, school should take responsibility through giving multicultural education to students, such as guidance and counseling through various services. Therefore, a counselor is required to have reliable multicultural competence. The kind of referred counselor is School Counselor with multicultural 
competences, such as knowledge, understanding, and awareness in effectively working with different cultured students (Wibowo, 2019).11

It is different to counseling profession in United State which has been combining theory and practice of multicultural competence (Sue and Sue, 2003) ${ }^{8}$, in our country, review about multicultural in counseling is rarely found and limited (Supriyadi, 1998) ${ }^{10}$. Training about multicultural competence of counselor in United State is vastly developed with various methods (Koch \& Dollarhide, 2000). Meanwhile, in Indonesia, counseling competence training is still limited on various psychological approaches. Even, unfortunately, multicultural competence is not explicitly added into Counselor Competence Standard (Mufrihah, 2014). ${ }^{5}$

In theoretical review, it is found various definitions which clarify concept of multicultural competences. Fantine (2007) stated that multicultural competence is competence among cultures which are complex and need direct interaction in the field ${ }^{1}$. This competence covers awareness, knowledge, and skills to connect effectively to various ethnics and cultures from various groups. Multicultural competence can be defined as unique categorization of awareness, knowledge, and skill to work in a culture efficiently (Hladik and Jadama, 2016) ${ }^{2}$. Fuertes and Funterto formulate that multicultural competence is a counseling skill in integrating theoretical and practical approaches to assess and intervene in various human backgrounds which are important to support counseling process and success (Roysircar, 2003). ${ }^{8}$

Multicultural competence has been so long being reviewed and has resulted various theoretical models. One of them is a model developed by Deardorff. According to this model, multicultural competences consist of four components: Multicultural knowledge, cultural activity of terminology understanding, multicultural awareness, and multicultural communication skill (Hladik and Jadama, 2016).

This research aims to obtain description of how Junior High School counselor perception to multicultural competence heretofore. Meanwhile, the findings are expected to be applicable in recommending any concerning party to follow up with various policy programs.

\section{Methodology}

This research was promoted to 115 Junior High School guidance and counseling teachers in Semarang. By using closed questionnaire, it was used to reveal their perceptions about multicultural competence reviewed from: (1) multicultural competence importance for counselor, (2) requirement of multicultural competence in providing school counseling, (3) knowledge about multicultural competence, (4) multicultural competence task, (5) multicultural competence implementation in Guidance and Counseling service, and (6) participation in that competence training. The data analysis method is descriptive statistic by using percentage calculation.

\section{Results and Discussion}

The obtained data analysis results are shown below:

\begin{tabular}{|c|c|}
\hline Perception Quality & Percentage $(\mathbf{N}=\mathbf{1 1 5})$ \\
\hline Important & 70 \\
\hline Sufficiently Important & 30 \\
\hline Not Important & 0 \\
\hline
\end{tabular}

Table 1: The Importance of Multicultural Competence for Counselors

From the table, it shows that most of the guidance and counseling teachers whom became the respondents perceived that multicultural competence was important for them to promote guidance and counseling at school.

\begin{tabular}{|c|c|}
\hline Perception Quality & Percentage $(\mathbf{N}=\mathbf{1 1 5})$ \\
\hline Need & 100 \\
\hline Does not need & - \\
\hline
\end{tabular}

Table 2: Requirements of Multicultural Competence in Counseling Service

All respondents as shown in table 2 had positive perception about needs of multicultural competence. It could be interpreted that all respondents assume a counselor needs this competence in providing Guidance and Counseling service at school.

\begin{tabular}{|c|c|}
\hline Perception Quality & Percentage $(\mathbf{N}=\mathbf{1 1 5})$ \\
\hline Knowing & 86 \\
\hline Not Knowing & 14 \\
\hline Table 3: Multicultural Competence Knowledge
\end{tabular}

The table describes that most of the respondents had knowledge of multicultural competence concept and theory. Only a few of them perceived themselves to not know the competence. 


\begin{tabular}{|c|c|}
\hline Perception Quality & Percentage (N= 115) \\
\hline Inadequate & 6 \\
\hline Sufficiently Adequate & 34 \\
\hline Requiring development & 60 \\
\hline
\end{tabular}

Table 4: Multicultural Competence Mastery

The table shows that most of respondents perceived themselves to develop their multicultural competence and the other assumed that they had sufficiently adequate multicultural mastery.

\begin{tabular}{|c|c|}
\hline Perception Quality & Percentage $\mathbf{( N = 1 1 5 )}$ \\
\hline Ever & 100 \\
\hline Never & - \\
\hline
\end{tabular}

Table 5: Implementation of Multicultural Competence in Guiding and Counseling service

Dealing with multicultural competence implementation in guiding and counseling service, the table shows that all respondents perceived themselves to have ever done it. However, it was not known how far their implementations were.

\begin{tabular}{|c|c|}
\hline Perception Quality & Percentage $(\mathbf{N}=\mathbf{1 1 5})$ \\
\hline Ever Joined & 6 \\
\hline Never Joined & 94 \\
\hline Table 6: Participation in Multicultural Competence Training
\end{tabular}

Table 6: Participation in Multicultural Competence Training

From the table, almost all guidance and counseling teachers perceived themselves to have never joined training which had purpose to develop multicultural competence of a counselor.

The percentage analysis result shows facts that school counselors perceived themselves that multicultural competence was important and needed in promoting guiding and counseling service at school. Conceptually, they knew what multicultural competence was, included its benefits in counseling. They also had ever practiced it based on their own mastery capabilities. However, in the other hand, they learned that their skills had not been maximum and they needed to develop it. They also acknowledged that there were not so many multicultural competence trainings which made their participations to join such training lower.

The findings supported Supriadi's research (1998) that rare multicultural counseling review in Indonesia made lower research interest which focused on those issues. Furthermore, it would influence to lower interest in developing multicultural competence. Furthermore, explicitly, multicultural competence is not written in Indonesia Counselor Competence Standard.

From these research findings, they implicate the needs of standard formulation based on Indonesia cultures about counselor multicultural competence done by professional organization, in this case - Indonesia Guidance and Counseling Association (ABKIN). There is also a need to recommend further research and development to find out effective multicultural competence training model which remains referring to Indonesia cultural characteristics to fill in current multicultural competence training.

\section{Conclusion}

Based on the findings and discussion, it could be concluded that most of the Junior High School counselors in Semarang had positive and meaningful perceptions about multicultural competence which they assumed important and useful in carrying out their tasks. However, they perceived that there is a need of improvement in which, unfortunately, it has not been supported by competence training facility. The findings could be used as consideration for better policy formulation by professional organization and Educational and Cultural Ministry on concerning expertise. It could be also reference for further research about counselor multicultural competence development.

\section{Acknowledge}

In this occasion, I would like to thank the postgraduate director who had given research permission, to the promotor, co promotor, and promotorer member who has guided in this research; also, to Community of Junior High School Counselors at Semarang City. And for all Guidance and Counselor teacher who have participated as respondents in this research.

\section{References}

i. Fantini, A.E. (2007). Explory and Assessing Intercultural Competence. Http // csd. Wust.edu/ Publicata Document/. Pp 07-01.pdf.

ii. Hladik, J \& Jadama, LM. (2016). Multicultural Competence of Helping Profession Students, Cross cultural Comparison between Europa and Africa. Jurnal Procedia-Social and Behavioral Sciences, 217 : 669 - 678.

iii. Koch, G. \& Dollarhide, C.T. (2000). Using a Popular Film in Counselor Education: Good Will Hunting as Teaching Tool. Journal of Counseling and Education and Supervision, 39: 203-210. 
iv. Loekmono, Lobby JT. (2009). Pendekatan Konseling Lintas \& Multi Budaya. Pidato Pengukuhan Guru Besar Universitas Kristen Satya Wacana Salatiga.

v. Mufriah, A. (2014). Implikasi Prinsip Bimbingandan Konselingterhadad Kompetensi Multikultur. Jurnalpeloporpendidikan , 7 (1) : 73-85.

vi. Pedersen, P.B., Dragun, J.G., Lonner, W.J., and Trimble, J.E. (1996) Counseling Across Cultures. London: Sage.

vii. Pope, R.L. danReynold, A.L. (2008). Students Affairs Core Competences: Integrating Multicultur Awareness, Knowledge and Skill. Journal of College Students Development 38 (3) . 266-277.

viii. Roysircar, G. (2003). Multicultural Counseling Competence. Alexandria: Association for Multicultural Counseling and Development.

ix. Sue, D.W. and Sue, D. ( 2003) . Counseling the culturally different. Third ed Chicester: Wiley.

x. Sue,D.W., Aredondo, P., and Davis, P. ( 1992). Multicultural Counceling Competence and Standard: A Call to Profession. Journal of Counseling Development March/April 1992 Vol. 70 : 477 -487.

xi. Supriadi, Dedi. (1998). Konseling Lintas Budaya: Isu -isudan Relevansinya di Indonesia. Pidato Pengukuhan Guru Besar Universitas Pendidikan Indonesia Bandung.

xii. Wibowo, MunginEddy. (2019). Konselor Profesional Abad 21. Semarang: Unnes Press. 